\title{
"To whom does the land belong?": Mogobe Bernard Ramose talks to Derek Hook ${ }^{1}$
}

Mogobe Bernard Ramose is an extraordinus professor of philosophy at the University of South Africa's department of Philosophy, Practical and Systematic Theology. Much of his theoretical work and writing has followed Sobukwe's political thinking, certainly inasmuch as it foregrounds the Pan-Africanist Congress's slogan "Izwe Lethu" ("Our land") as a crucial point in contemporary debates about social and historical justice. This insistence on the sovereignty of the African people has proved foundational to Ramose's philosophical and legal theorising. A focus of Ramose's work is ubuntu, the Nguni concept in which philosophy, ontology and ethics are thought together in a holistic approach to human-ness. Ramose's understanding of justice as balance and harmony demands the restoration of justice by reversing the dehumanizing consequences of colonial conquest and by eliminating racism. His work displays an unwavering commitment to questions of justice, politics, ethics, and truth. The fact that Pan-Africanist questions that emerged in the 1960s and 1970s are still relevant and pressing today, in 2016, demonstrates both the continued relevance of a figure like Sobukwe, and that outstanding questions of justice still pervade the contemporary South African social sphere. The importance of Ramose's inclusion here in a consideration of the psychosocial discussion of Sobukwe's legacy lies in his (Ramose's) continued insistence on the role of justice, ethics and, crucially, the concrete issue of land dispossession in any elaboration of psychological or philosophical engagement with Black Consciousness or Pan-Africanist thinking. The

Derek Hook, Duquesne University, Pittsburgh, USA 
attempt to confront, challenge and eradicate racism in the contemporary South African context means nothing, for Ramose and Sobukwe alike, if these issues are not absolutely prioritized.

The addition of a few biographical details helps contextualize the interview. Like many African leaders and intellectuals, Mogobe Ramose had a training in Catholicism; he graduated from the Holy Trinity High School in Atteridgeville in 1968. In 1970 he enrolled for a degree at the University of South Africa majoring in philosophy, politics, and English studies. After completing his BA in 1973, Ramose started pursuing a degree in jurisprudence. This was a tumultuous time in South African politics, one in which Ramose was increasingly involved both in scholarly study and activism. Influenced by the radical pedagogy of Paulo Freire, a group of students and young activists went under the banner of the South African Student's Association (SASA) to Winterfell to practice this pedagogy of the oppressed. It was soon after this that the trip to Kimberley to meet Sobukwe was undertaken.

Following his increased political activism, the security police strengthened their efforts and attentions on Ramose and began harassing him and his comrades. At that stage Vincent Maphai, a trusted comrade and friend, came to Ramose with an offer to go to Europe on a scholarship and after receiving a mandate from the Black Consciousness Movement (BCM), Ramose left for the Katholieke Universiteit Leuven in Belgium. After his studies Ramose did not come back to South Africa. The situation in the country had worsened considerably and Ramose was warned by comrades and colleagues not to return home. Ramose's exile lasted until his return to the University of Venda in 1996.

Ramose has held many institutional affiliations in the course of his career. He was associated with the Katholieke Universiteit Leuven (1983-1986, and again from 1991-1993), the University of Zimbabwe (1986-1990), the Katholieke Universiteit Brabant (1993-1996), and the University of Venda (1997-1998). From 1999 Ramose has been affiliated with the University of South Africa as professor of philosophy. Under his guidance, the Department introduced African philosophy as a core part of the undergraduate and postgraduate curriculum and until today it is the only philosophy curriculum in the country that includes African philosophy as one of its core modules.

This interview was conducted on the $23^{\text {rd }}$ August 2014 in Tshwane at the University of South Africa. It was edited by Terblanche Delport and Ndumiso Dladla who also added additional citations and biographical information. 


\section{Derek Hook (DH): So if I understand correctly there were some times where you met with Sobukwe or stayed with him in Kimberley?}

Mogobe Bernard Ramose (MBR): Yes, it was a visit to his home in Kimberley, Galeshewe.

\section{DH: That must have been in the 70s?}

MBR: In the 70s, that is correct.

\section{DH: And what were the circumstances of your visit, Prof?}

MBR: Well the reason is twofold I think. One is that I speak in "we" terms, because I was in a political context at the time, as I still am, but we thought that the fact that certain political activists were forcibly removed from the communities from which they come does not mean we agree with their isolation. Because they must not feel isolated by us who appreciate and recognise their contribution, we thought it is better to make that concrete by visiting them so that they actually note, and know, that they are not alone, and that what they have been doing is not in vain. To add to that the other reason was that we were also not starting from a clean slate. There were other people before us in the struggle and so they have had certain experiences, and we would like to know their experiences, to even receive advice from them and that is why we went to go see him.

\section{DH: So prof, were you part of the Black Consciousness Movement [BCM] at the time you went to visit Sobukwe?}

MBR: Yes, I was part of the Black Consciousness Movement when we visited him at the time. Because we arranged in advance to go and visit him, we were able to see him and have some discussions with him. One of the things that struck me, I don't know about my other colleagues with whom I was, was just his calmness. A very calm gentlemen. Very, very, calm. But it didn't mean that beneath that calmness there was no revolutionary fire, otherwise he would not have been where he was. It was good to engage in conversation with a man as calm as himself. The conversation was quite good. And so, a number of points I picked up during the conversation, and even prior just reading about him, but now the benefit of seeing him in person, was quite revealing to me. One of the points we discussed was the inspiration and the theory behind the slogan Izwe Lethu, "Our land". It became very clear to me that there is a view of the

\footnotetext{
George McCall Theal was a historian and ethnographer that wrote widely on southern Africa in the late 19th and early 20th century. His writings can be considered a paradigmatic example of a historiographical (and in many respects racist) orthodoxy that dominated thought in South Africa.
} 
history of this country, a certain perspective that many indigenous peoples conquered in the unjust wars of colonisation have, that the territory known as South Africa today, belongs to these peoples from time immemorial. The perception and understanding of this point was quite clear and explicit in the discussions we had with Sobukwe. What exactly did it mean? At that time we did not have the advantage of history as we have it today. At that time there was still the historical perspective of people like [George McCall] Theal ${ }^{2}$. Theal who imagined that the Khoi and the San people grew like grass from the South African soil while the rest of us migrated from the North. This type of historical knowledge, as it were, persists of course until today. Quite recently I was in a bookshop in Germany, and I went to a children's section of books. There I picked up a book, and one of the questions - it was just a book on general knowledge - asked in that book was, "who are the oldest inhabitants of Africa?" The answer was the Khoi and the San peoples. Well you see, this is why I am saying this is really general knowledge. The South African Historiography, a very definitely interested historiography, projected this image of history. And it is so that when one reads pieces about Mapungubwe one finds that there is a very attractive phrase that appears in so many pieces - attractive from a historical point of view - and this phrase is "the kingdom of Mapungubwe and the peoples of Mapungubwe are actually the ancestors of the Khoi and the San people". So it is quite recent because Pretoria University was able to conceal these findings for too long - at least for four decades ${ }^{3}$. But, even when you read literary fiction like Zakes Mda's The sculptors of Mapungubwe (2013) you see the Khoi and San people are there, they are even regarded as non people, there is some kind of discrimination there. So what I am getting at is that this concept of 'from time memorial' can now even be reinforced if this historical piece can be corroborated.

\section{DH: Prof that's really important material. Could you explain what it was like that day arriving in Kimberley and meeting Sobukwe for the first time?}

MBR: Right. Well I have already stated something about his calmness. Really, it is something that is him; serenity is another name for Sobukwe if you like. Really serenity is another name for him. Well, we knocked on his door and it was one of the members of the family who opened, not himself. Because we were expected, there was no problem, especially because some of the people in Kimberley were Black Consciousness at the time, for example Job Mokgoro, whose wife is today a judge [Yvonne Mokgoro]. Yes, together with them we managed because we liaised with them to be able to go there. And so there you enter the home, you see that it is not a mansion, it is not a mansion. It is a home like so many other black peoples' homes and in spite of the fact that it is small

The initial excavation of Mapungubwe was done under the supervision of the University of Pretoria which is still in possession of many of the excavated objects. 
in size, when you enter where he is, and you find him seated, he stood up, as even if he is no king, he stood up with majestic dignity to greet each one of us. And then invited us to take seats. So there you see something also of the man, namely his courtesy. In fact as you may well be aware, that for us was a genuine Ubuntu ${ }^{4}$ welcome. When we left afterwards, one of the comments that we made about him was exactly that whew, Onale botho - botho as you know is another word in Sotho for the Nguni word Ubuntu. So for us this was the man, the man who was in his courtesy and hospitality the living example of Ubuntu.

\section{DH: How many of you were there? And did you stay at his house?}

MBR: No we did not. That is why we arranged before the time. Because we were a group of 5 people accommodation had to be arranged beforehand. Some of us slept at one friend's place and others by another friend's place, so we split as far as accommodation is concerned. But we went there together. We arrived the night before the day that we were to go see him. We arrived the night before, had a long conversation and, as I was saying about the courtesy, we surely did not miss a cup of tea, or a glass of water. We did not have to ask for a cup of tea or a glass of water, it was always there. You see this welcoming, this openness to people, to say you are welcome, it actually confirmed us in our wish to say to him "you are not alone". It was, however, more towards the reverse: he was never alone, he was actually saying to us, "you are not alone, I am with you". He did not have to say the word: his whole disposition declared that we are together in this. Certain words need not have been said at all, his overall deportment was by itself a number of messages at the same time.

\section{DH: Do you think that it was a happy time for him, the Kimberley time? I ask that because Kimberley followed a long period of imprisonment and separation from his beloved wife and children, and also because a younger generation was showing so much interest in his thought and actions.}

MBR: Well happy is, as you may know, quite a difficult word. But I if you mean happy in political terms, I think yes. The people that I mentioned that were part of the liaison process were very young compared to him in terms of age. Very young people and for him to have succeeded to strike a rapport between himself at his age, and people so young, it must say something about the man. It must say something about him, and even something about those that were part of our contingent. You know for us African people, age is a reason to treat someone with greater and greater respect and that sometimes

Ramose is here not referring to Ubuntu as a theoretical construct, but Ubuntu as an ethical relationship to the world. See Ramose (2002). 
means taking distance from the elders. In this case, from a political point of view, there was more proximity than distance, despite the difference in age. So I think that must have been a source of happiness, and even gratitude, to the young ones that actually now will take over the torch, and continue. I think it was a reflection of what I said earlier about his deportment, the way he received us was like "wow, you are coming to tell me that I am not alone. Well I want to tell you we are together". And he can say that only if he understands and appreciates the power of the situation. So I think from that point of view in political terms, I would say I saw a happy man. I saw a man who understood that the 90-day detention class did have repercussions far beyond his Kimberley. We were not from Kimberley to start with. He knew we were from Pretoria. If one considers the distance, just the distance, and that people should prefer to break the distance by seeing you in person, I think as an adult you really would appreciate it. Even when we take this out of the political context, and simply look at it from an African cultural perspective, elderly people normally exude joy and happiness when the young are around them. So just from that point of view, I think also the youth there saw a happy man. I didn't see on his forehead or in his smile, I didn't see traces of regret or sorrow. That I did not see. I still have quite a vivid picture of a man calm with a smile and not a grin. A real smile.

\section{DH: What did he look like?}

MBR: Well, he actually, first of all, was not clad in formal dress. He wore a darkish shirt. I do not mean black; I mean something between grey and khaki. And it was a short sleeve shirt, between grey and khaki. The way he walked did not give me the impression that he wore shoes. I thought he wore sandals on that day. This was a mood of relaxation, he was relaxing. He did not carry himself like an old man. He did not have a walking stick with him, nor did he have braces for his trousers. He still had a belt on. I think for some, if you have a brace, that is an old man, he cannot even manage a belt any more. But he was able to really walk gracefully, sit down and relax gracefully. Picking up a glass of water or a cup of tea from the table was not a problem, because he was not shaky, he did not take it like he had the hand of an old man, a hand that was shivering towards the object.

\section{DH: The other question I have really wanted to ask is about the meeting between Sobukwe and Biko. There are a lot of sources and traces in the archives that refers to a meeting between them. For example, in May 1975, when Sobukwe goes to Umtata for his mother's funeral, on the way he passes by to King Williams Town to meet Biko. In some ways, for me, this represents one of the great "unseen scenes" in South African history, but no one seems to know exactly, or no one can really describe what could have been discussed between the two. Do you maybe have any sense of those}




\section{meetings or what they would have been like? What was discussed, what did Sobukwe think upon seeing and meeting with this young man who was going to go on to become such an important figure for black consciousness in South African politics?}

MBR: No I actually do not know the details I am afraid. The details I do not know. I did hear about the meeting and what I heard was just superficial things. Rather superficial in the sense that, well, they met. I think one of the things that could be drawn from such a meeting is that it was understood that the black consciousness movement should not find itself wholly in support of the ANC, nor wholly in support of the PAC, at the expense of the other. We must function in a way that we can see the good that there is in the ANC, and the good that there is in the PAC and still retain our identity. I mention this because when we had talks before my departure for Europe ${ }^{5}$ we discussed this as it was called, at the time, "black consciousness policy of positive neutrality", specifically in relation to these two organisations. Why was I asked specifically to go to Europe? I was asked specifically because as an activist in the country I had the idea that the struggle is here but then I had an offer of a scholarship, and I communicated to the people and said, well this is it, but I do not want to go, because the struggle is here. They said no, we have a different view. You better take the opportunity and go, because in that way we can formally appoint you as a representative of the BCM and therefore you can now represent us there. That was the basis, and during discussions about this trip is when I got to understand that - this was one of the fruits of that meeting - we must think positively about both the ANC and the PAC but not commit ourselves to either. You see? And I saw that as something of the greatness of Sobukwe in the sense that for another politician it would have been easy to say "no, I think we have more ideological and political affinities, therefore when you are as you are, you must at the same time identify with us". No, this kind of narrow-minded thinking was not a part of him. This is what we really did, after our discussion with Sobukwe I travelled to Durban to get a formal letter - unfortunately from another activist who died, Thamisani - so as to not be a clown and say I am representing the BCM in Europe when there is nothing I can show for it. I think this anecdote yet again confirms that Sobukwe was not a man of calmness only in appearance ... he is always serene about very delicate life and death issues. He knows he must not put his interest before these issues. This positive neutrality of his is one example I can give.

\section{Derek Hook (DH): Extraordinary. Given that he was the president of the PAC and the Africanist approach was very much his set of values, it is remarkable how open handed he was in thinking about}

\footnotetext{
Ramose went to Europe on the mandate of the BCM in 1977.
} 


\section{the ANC taking into account the opposing views. It sounds like a large part of the discussion in the meeting wasn't even necessarily explicitly political; it was more a gesture of support?}

Mogobe Bernard Ramose (MBR): Well there was a lot of politics, that's why I started with the Izwe Lethu issue. That's why I started with that because it showed, like I was saying, now that we have this Mapungubwe story, there is no reason why we should be soft on the point that this is our land (Izwe Lethu). This was one of the intensive points of the discussion that had immense consequences, because if it is our land as we maintain it is then whoever takes this land by force surely cannot be regarded as the rightful owner of the land, so from that point of view the question now becomes: if there should be any change at all in the country, and this change does not answer this question - to whom the land belongs? - then of course that change is not complete. There is unfinished business precisely regarding who is the owner of the land. You may have seen in my writings that actually land ownership in that sense does not pertain to the questions of private law, the right to private property, so and so has got the piece of land ${ }^{6}$. No this one is specific. It is the question of sovereign title to territory, and that means for the understanding of many people it is difficult to marry the idea that you can be a king or queen without territory. Even when King George came at some point to South Africa there was a traditional poet who was welcoming him with a poem in Northern Sotho, a wrong poem I might add. I quote the poet to show two things: One how we understand what it means to be a king, and secondly to show that the poet actually gave the king of England concessions that he was not supposed to have. Now what do I mean by this? First, he [the poet] mentions that today we see that in South Africa has arrived the King, owner of the soil. He is not King, the poet said, by clever and cunning means. No, he is King by virtue of title to territory. I would say that explains the concept that we have of a King. But to attribute that to King George at the time when he is actually the culprit of having expropriated the land by force, that is where the problem lies. He was an old man of course, but still you can see that this idea of being a king with a kingdom in the territorial sense of the word is very fundamental in our understanding the concept. When you do not have this sovereign title to territory it becomes a mismatch conceptually and practically to be a king. And from that point of view, one would say the Izwe Lethu slogan of the PAC is still important in today's South Africa because today's South Africa is yet to answer the question. You see? So that was one of the areas of discussion. And I think my writings remain faithful to that because I very explicitly and directly distinguish between sovereign title to territory and what consequences will grow from there, and very simply private law property law. These are two different matters.

\footnotetext{
6 See Ramose 2002 \& 2007.
} 
Another point of discussion was precisely, hell! Pan African! Well, that means you are racist? You are discriminating. If you are not an African, then what? And why Pan African? So is it racist? That was also a point of discussion and he was pleased that this particular point of Pan Africanism was being debated and developed. I think even in some of the documents collected by people like Thomas Karis and Gail Gerhart, this full volume From Protest to Challenge (2013) it is very clear that actually Pan Africanism is quite important both as a philosophy and as an idealism, because it is a necessity arising from the exigencies of the situation. And so from that point of view, one should understand that - at least at that time during discussion - what Pan Africanism aims to achieve is two things basically. One is the ascension of the right to be African. You need to assert the right to be African, and the right to be African in this context means the right to be human, because it is the humanity of the African that is called into question. The right to be African is thus also the right to be human. Pan Africanism cannot be seen as racist, precisely because the centre of the credo is that there is only one family, one human family, and so that human family is the human race. Races in plural is problematical from the perspective of Pan Africanism, because it is wilful submission to racist thinking, and this is what is being resisted by Pan Africanism. It is actually racism that has made sure that the derogation of the African humanity would not take place. How can Pan Africanism then say I want racism back? No! What needs to be argued for, and not even restored, this here is not even a case of restoration, as if the African people did not have human dignity before, no it was always there, it was in the best of cases just made invisible, and it is this visibility that we want. And once we have this, we are not visible as Africans in the first place; we are visible as human beings. It is precisely this visibility as human beings that make us embrace everyone else as another human being. What you are calling for is yes, let everyone be human. Do not introduce racism as a blinker to make invisible what has always been there. So that discussion around whether or not Pan Africanism or Pan African Congress was racist did arise, and this is one of the insights that come out of him. No the human race is the only race. Just one family of human beings and like in every family, some of the children will be fat, others lean. Others will be short, others tall. They may even have different complexions, so it is not a question of what colour are they, these are just nice accidents of nature that we can deal with. But we deal with them in relation to the point that what we share as capable human beings, what we have in common is our humanness, the rest will follow. So I think also, without using the label Pan African or Black Consciousness, that this is one of the trajectories of my writings exactly, it is exactly this. That is also in a way confirming one of the intentions of our visit to people like Sobukwe, because we also needed their counsel and wisdom on certain matters, and so this is what it was, to understand that it does not make sense, to really think in terms of colour. When you reason in the context of how human relations should be structured, do not reason from the point of view of colour. 


\section{DH: The way that you have woven these things together, the scene, the story of the meeting, of discussing, and these political points are really helpful, because it helps communicate philosophy through the historical event. Before we end the interview are there any last thoughts that you might have had? Something else that was maybe discussed, or how it ended, or what you came away thinking about after the meeting?}

MBR: Well exactly the point that, as you know, in those days the terminology was the "Sobukwe Clause"7. So I had to find out how does he feel about this naming of the Sobukwe Clause. The answer was very clear and simple. It was that law is at its best when it recognises, when it protects and promotes human dignity. And of course the Sobukwe Clause is totally against that, so you must be aware that law can be an instrument of oppression and suppression. This may not happen if there is any change at all in the new dispensation, they must guard against making law the enemy of human dignity. You see today we have a so called new constitutional dispensation but I have argued in my writings that this is not very serious because it is racially inspired and yet claims that it is anti-racialism. This fundamental contradiction makes it a problem, because it still raises the question for us that if it is true that this is the best constitution that we ever could have had, surely there were opportunities for this constitution to come up. Even from the side of the conqueror, the posterity of the conqueror, there were honest and brilliant political and legal minds that argued for this type of constitution in the 60 s. I believe it was Davenport an academic from the University of Cape Town, who in the journal Acta Juridica argued strongly for this type of constitutional dispensation ${ }^{8}$. This was in the 60 s, it was during the time when Sobukwe was a threat, it was during the time when the Afrikaner was really keen to be more and more integrated.

\section{DH: What kind of dispensation was he arguing for?}

MBR: He was arguing for the constitutional supremacy, the constitutional principle that should govern South Africa. Davenport was arguing that South Africa should be

\footnotetext{
The "Sobukwe Clause" was part of the General Law Amendment Act No 37 of 1963 which allowed people already convicted of political offenses to be further detained for a further 12 months by an act of parliament. The clause was named after Sobukwe; it was brought into law to keep Sobukwe imprisoned on Robben Island for 6 years after he had served his initial 3 year sentence.

\& Ramose is referring here to T R H Davenport's 1960 article in Acta Juridica on civil rights in South Africa between the periods 1910-1960. An extract of this article, that Ramose (2001: 16) cites, reads: "Several modern critics of the South African constitution have argued cogently that the foundation fathers of the Union created the wrong sort of constitution for this sort of country, urging that greater decentralization ... plus the incorporation in the written constitution of a bill of rights enforceable by a more independent judiciary ... would have made it a more acceptable and enduring document. With these opinions we need not quarrel. The absence of safeguards of this sort resulted in the attribution of supremacy to a legislature which is not and never has been thoroughly representative, and which has since shown a disposition to use that supremacy with singular lack of restraint".
} 
a constitutional supremacy and not a parliamentary supremacy. Of course he was a voice in the wilderness. Suddenly he is resurrected without even recognising him. You see what we got from Sobukwe is that even if it is a white person speaking we must remember that it is a white human being speaking and they may be telling the truth. That is why I am saying that regardless of the colour of Davenport, at the time he was announcing a truthful message, a message that was ignored because people had other interests. Suddenly the same Davenport is resurrected without recognition, and now we are told that parliamentary supremacy must be abolished as a constitutional principle, and it must be replaced by the supremacy of the constitution. The timing is wrong, and the wrongness of the timing, makes the content of the constitution problematical precisely because it does not address the issues that it is supposed to have addressed. This for me is the time to let Davenport speak again. To let him speak. Really let him speak.

DH: Just to clarify two things for understanding. One is that thought that had come to you after meeting Sobukwe, or was it his explicit response? Had you asked him about the Sobukwe clause, and then he gave you the point about law should serve human dignity rather that oppose it?

MBR: He gave that point, but only now, on further reading and reflection, could I see the point Sobukwe was trying to make.

DH: There is a nice historical symmetry here, so correct me if I am wrong but one of your arguments then is not just the timing but also the content of the South African constitution is itself problematic and in a way one of the benefits of Sobukwe's historical legacy is to make us aware of how that document is problematic. Furthermore, and this is extrapolating a little bit, it is almost as if you could take that historical scene where the PAC cautions against the Freedom Charter and the problematic things that are being enshrined in the Freedom Charter - which of course is strong in Sobukwe's speeches and writings - and make the same argument today in relation to the constitution. This is part of Sobukwe's legacy, the critique against the constitution that contains many of the same problems that the PAC cautioned against in the Freedom Charter. That argument holds?

MBR: It holds, it holds yes. 


\section{DH: And the last thing I wanted to clarify is exactly Davenport's position. Was he arguing for parliamentary supremacy or for constitutional supremacy?}

MBR: Constitutional supremacy, because when you have constitutional supremacy as the basis for constitutional reasoning and thinking, then it means that everything else would be tested against the constitution. At that time it was not the case. That is why he was arguing that South African society requires a constitutional supremacy. At the time it was parliamentary supremacy, where parliament had more power than the constitution.

\section{DH: The Sobukwe clause!}

MBR: Exactly.

\section{DH: ... a case in point. So in other words you would not be able to promulgate something like the Sobukwe Clause today if it is not in the constitution. There is one further point to make. Constitutional supremacy is good, or preferable. But what happens if there are problems in the constitution?}

MBR: It cannot even now from a historical ethical point of view be called the Constitution of the people of South Africa. It is a problem. Ethically and historically speaking it is a problem. You can see it also in the longest clause of the current constitution. The longest clause in constitutions is normally the clause that has to do with the abrogation of rights. When rights are going to be suspended or there is a state of exception, then the constitution is very long. The clause there is long, it tells you when and why and what not to do. Now here, even before you read the constitution the longest clause strikes you, you see it clearly. It is the clause about property rights. Whose property rights, taking into account the history of the territory, are being defended? So you can see, the timing is related also to the content. Ethically speaking we cannot therefore call it "the Constitution of the people of South Africa". Even if you say the principle of constitutionalism is correct, the fact of the matter is that the application of the principle at that particular time was mistaken and it remains mistaken. Instead of promoting justice, it goes exactly against what Sobukwe told us with reference to the 90 day detention clause. Detention without trial is clearly an instance of law working against the protection and recognition of human dignity. This is what we have now with the new dispensation: a law that actively retards the process of justice for the indigenous conquered peoples of South Africa. It is quite ironical that most of the so called negotiators including Mandela himself were trained lawyers, how 
could they not see that? Seriously ironical. [Cyril] Ramaphosa, lawyer, Matthew Phosa, lawyer, Mandela, lawyer. Where did they study the law, how could they not see? I don't think it makes sense! It just cannot make sense.

\section{References}

Davenport T R H (1960) Civil rights in South Africa 1910-1960. Acta Juridica, 13.

Karis, T \& Gerhart, G (eds) (2013) From protest to challenge. A documentary history of African politics in South Africa, 1882-1990: Volume 3 - Challenge and violence, 1953 - 1964. Johannesburg: Jacana.

Mda, Z (2013) The sculptors of Mapungubwe. Johannesburg: Kwela.

Ramose M B (2001) An African perspective on justice and race. Polylog: Forum for Intercultural Philosophy, 3. http://them.polylog.org/3/frm-en.htm\#s7

Ramose M B (2002a) African Philosophy through Ubuntu. Harare: Mond Books.

Ramose M B (2002b) I conquer, therefore I am the sovereign: Reflections upon sovereignty, constitutionalism, and democracy in Zimbabwe and South Africa, in Coetzee P H \& Roux A P J (eds) (2002) Philosophy from Africa: A text with readings. Oxford: Oxford University Press.

Ramose M B (2007) In memoriam: Sovereignty and the new South Africa. Griffith Law Review 16(2), 310-329.

Theal, G M (1910) The yellow and dark-skinned people of Africa South of the Zambezi: A description of the Bushmen, the Hottentots, and particularly the Bantu, with fifteen plates and numerous folklore tales of these different people. Swan Sonnenschein \& Company. Reprintred, New York: Negro Universities Press/ Greenwood Publishing, 1969. 